\title{
Rhizobium ciceri sp. nov., Consisting of Strains That Nodulate Chickpeas (Cicer arietinum L.)
}

\author{
SARAH M. NOUR, ${ }^{1,2 *}$ MARIA P. FERNANDEZ, ${ }^{1}$ PHILIPPE NORMAND, ${ }^{1}$ \\ AND JEAN-CLAUDE CLEYET-MAREL ${ }^{2}$
}

\begin{abstract}
Centre National de la Recherche Scientifique, Unité de Recherche Associée 1450 "Ecologie Microbienne du Sol," Université Lyon I, 69622 Villeurbanne Cedex, ${ }^{1}$ and Institut National de la Recherche Agronomique, Laboratoire de recherche sur les Symbiotes des Racines, 34060 Montpellier, ${ }^{2}$ France
\end{abstract}

\begin{abstract}
The taxonomic status of 16 collection strains of chickpea (Cicer arietinum $\mathbf{L}$.) rhizobia which were previously determined to belong to two groups (groups $A$ and B) were compared with reference strains belonging to different genera and species of the family Rhizobiaceae. We used the following taxonomic, phylogenetic, and phenotypic characteristics and approaches to study these organisms: DNA homology, guanine-plus-cytosine content, restriction fragment length polymorphism of the amplified 16S-intergenic spacer rRNA gene, partial 16S rRNA sequencing, and auxanographic tests performed with 147 carbon sources. Similar groups of chickpea strains were identified by the different approaches. The chickpea strains were found to belong to the genus Rhizobium regardless of the phylogenetic group to which they belonged (group A or B). All strains fell into a tight cluster which included Rhizobium loti and Rhizobium galegae, and the group B strains were closely related to $R$. loti. An analysis of partial $16 \mathrm{~S}$ ribosomal DNA sequences revealed identical nucleotide sequences for the slowly growing strains and fast-growing strains that were used as representatives of groups $A$ and $B$, respectively, and these organisms fell into the Rhizobium-Agrobacterium lineage. When the sequences of these organisms were compared with the partial sequences of Rhizobium huakuii and $R$. loti, one- and two-nucleotide mismatches were observed, respectively, indicating that the chickpea rhizobia are closely related to these two species. The DNA-DNA hybridization data revealed that the chickpea rhizobia exhibited low levels of homology (Iess than 17\%) to previously described Rhizobium and Bradyrhizobium species. Moreover, when we compared chickpea strains to $R$. loti and $R$. huakuii, the most closely related species as determined by the partial $16 \mathrm{~S}$ rRNA sequence analysis, the homology values ranged from 21 to $52 \%$ and the $\Delta T_{m}$ values were greater than $5^{\circ} \mathrm{C}$ $\left(\Delta T_{m}\right.$ is the difference between the denaturation temperatures of the heterologous and homologous duplexes). These results confirmed that the rhizobia that nodulate chickpeas cannot be assigned to a previously described species. Within the chickpea rhizobia, the DNA homology values obtained when members of groups A and B were compared were less than $38 \%$, indicating that the group A and group B organisms belong to different species. Furthermore, these organisms can be distinguished from each other by the results of phenotypic tests. We propose that the group B chickpea rhizobia should be assigned to a new species, Rhizobium ciceri; UPM-Ca7 is the type strain of $R$. ciceri.
\end{abstract}

Currently, the bacteria which form nitrogen-fixing nodules on leguminous plants are divided into three genera, Rhizobium, Bradyrhizobium, and Azorhizobium. According to Bergey's Manual of Systematic Bacteriology (24), the genus Rhizobium contains three species, Rhizobium meliloti, Rhizobium loti, and Rhizobium leguminosarum (with three biovars, $R$. leguminosarum bv. phaseoli, $R$. leguminosarum bv. trifolii, and $R$. leguminosarum bv. viciae). Since the publication of Bergey's Manual of Systematic Bacteriology, the following five new species have been recognized: Rhizobium galegae (28), Rhizobium fredii (37), Rhizobium huakuii (7), Rhizobium tropici (29), and Rhizobium etli (38). Several other rhizobial groups have been described but have not been named yet $(2,47)$.

The rhizobia that nodulate chickpeas (Cicer arietinum L.) have been studied intermittently, and in all of the taxonomic studies of the Rhizobiaceae that have been performed either no strain or only a few strains belonging to this group were included. In Bergey's Manual of Systematic Bacteriology (24), the chickpea rhizobia are classified as members of either $R$. lot $i$

* Corresponding author. Mailing address: U.R.A. C.N.R.S. 1450 "Ecologie Microbienne du Sol," Université Lyon I, Bat. 741 bd. du 11 Novembre 1918, 69622 Villeurbanne Cedex, France. Phone: (33) 7244 82 89. Fax: (33) 724312 23. Electronic mail address: NORMAND@ ECOSOL.UNIV_LYON1.FR. or an undetermined Bradyrhizobium sp. group. The separation of these organisms into two different genera was based on the wide range of generation times observed with the strains, which led to classification of the fast and slow growers into the genera Rhizobium and Bradyrhizobium, respectively. In support of this separation, Chakrabarti et al. (6) determined levels of DNA-DNA hybridization for two slowly growing and two fast-growing chickpea strains and found very low levels of homology between members of the two groups.

Characterization of the fast-growing Lotus rhizobia was based on the results of an extensive study that included various strains that belonged to the Rhizobiaceae and were isolated from a wide range of host plants; these strains included three chickpea isolates (9). Relying on this report, Jarvis et al. (22) described the new species $R$. loti (with type strain NZP 2213), which was isolated from Lotus corniculatus. Two of the three chickpea strains tested exhibited 85 to $88 \%$ DNA homology with $\mathrm{CC} 809 \mathrm{a}$, an isolate that was obtained from Lotus marocannus and was later assigned to $R$. loti $(9,22)$. However, it is important to note that this strain exhibited only $47 \%$ DNA homology with strain NZP $2213^{\mathrm{T}}$ ( $\mathrm{T}=$ type strain). According to Wayne et al. (41), strains that exhibit DNA reassociation values of less than $70 \%$ do not belong to the same species. Thus, the genomic group that includes CC809a and the two chickpea strains should not be assigned to $R$. loti. Furthermore, Chakrabarti et al. (6) determined levels of DNA-DNA hybrid- 
ization for four chickpea strains and NZP $2213^{\mathrm{T}}$ and found very low homology values ( 8 to $32 \%$ ) regardless of the generation times of the organisms.

On the other hand, extensive studies have demonstrated the uniqueness of the chickpea rhizobia. The results of host specificity experiments (16) clearly distinguished distinct crossinoculation groups; 70 of the 71 chickpea isolates examined nodulated only the original host plant and did not nodulate the 88 species examined that belonged to the families Fabaceae and Mimosaceae. Similar conclusions were reached by Dadarwal (10), who studied the cross-infectivity of chickpea rhizobia by using cowpea group hosts. Immunochemical approaches have revealed that there are no serological cross-reactions between chickpea rhizobia and other Rhizobium species $(10$, 26). Cadahia et al. (5), using cultural characteristics and polymorphism of nifHD genes, did not find any criteria which defined groups within the chickpea rhizobia.

The numerous previously described contradictory conclusions about the characteristics and classification of the chickpea rhizobia were mainly due to the fact that few strains were tested or to the lack of approaches that permit workers to analyze genetic distances between genera. Few criteria exist for comparisons at the genus level; the most reproducible and universal criterion is the genetic distance between strains, as determined by $16 \mathrm{~S}$ rRNA sequences. In the case of chickpea rhizobia, no such sequences have been available.

In order to reexamine the biodiversity of the chickpea rhizobia, we tested some of the collection strains used by Cadahia et al. (5); the strains used were chosen to represent various geographical origins (33). Sixteen strains were compared by using multilocus enzyme electrophoresis, restriction fragment length polymorphism (RFLP) of the 16S rRNA gene, and more than 150 phenotypic characteristics (33). The results of all of the approaches were very consistent, and our data resulted in the delineation of two phylogenetically distant groups (groups A and B) and correlated relatively well with strain generation times (slow and fast growers). Nevertheless, the two groups which we distinguished must be precisely identified by comparison with other taxa belonging to the Rhizobiaceae.

Therefore, in order to determine the taxonomic status of the two chickpea rhizobium groups, we analyzed the same 16 strains and compared them with representatives of previously described genera and species belonging to the Rhizobiaceae, including $R$. loti (in which some of the chickpea rhizobia have been classified previously). Consistent with the proposed minimal standards for the description of species $(18,41)$, the following taxonomic, phylogenetic, and phenotypic characteristics and approaches were used to study the chickpea rhizobia: DNA homology, guanine-plus-cytosine $(G+C)$ content, RFLP of the amplified 16S-intergenic spacer (IGS) rRNA gene, partial 16S rRNA sequencing, and phenotypic characteristics, including auxanographic tests performed with 147 carbon sources.

\section{MATERIALS AND METHODS}

Strains and culture. The origins of the 16 chickpea collection strains and 13 reference strains belonging to the genera Rhizobium, Bradyrhizobium, and Azorhizobium used in this study are shown in Table 1 . The $R$. huakuii strain and $16 \mathrm{~S}$ rRNA sequence became available at a time when most of our experiments had been terminated. We included this organism in the 16S rRNA sequence comparisons and DNA homology study.
TABLE 1. Bacterial strains used

\begin{tabular}{|c|c|c|}
\hline Strain $^{a}$ & Host plant & $\begin{array}{l}\text { Source or } \\
\text { reference }\end{array}$ \\
\hline \multicolumn{3}{|l|}{ Rhizobium sp. group A } \\
\hline IC-72M & Cicer arietinum $\mathrm{L}$. & 5 \\
\hline $\mathrm{Ca}-7$ & Cicer arietinum $\mathrm{L}$. & 5 \\
\hline IC-6 & Cicer arietinum $\mathrm{L}$. & 5 \\
\hline IC-60 & Cicer arietinum $\mathrm{L}$. & 5 \\
\hline H-45 & Cicer arietinum $\mathrm{L}$. & 1 \\
\hline UPM-Ca142 & Cicer arietinum $\mathrm{L}$. & 5 \\
\hline UPM-Ca36 & Cicer arietinum $\mathrm{L}$. & 5 \\
\hline \multicolumn{3}{|l|}{ Rhizobium sp. group B } \\
\hline UPM-Ca $7^{\mathrm{T}}$ & Cicer arietinum $\mathrm{L}$. & 5 \\
\hline UPM-Ca116 & Cicer arietinum $\mathrm{L}$. & 5 \\
\hline IC-2091 & Cicer arietinum $\mathrm{L}$. & 1 \\
\hline IC-2018 & Cicer arietinum $\mathrm{L}$. & 1 \\
\hline 3HOa10 & Cicer arietinum $\mathrm{L}$. & 5 \\
\hline $3 \mathrm{HOa9}$ & Cicer arietinum $\mathrm{L}$. & 5 \\
\hline 522 & Cicer arietinum $\mathrm{L}$. & 5 \\
\hline USAB67 & Cicer arietinum $\mathrm{L}$. & 5 \\
\hline Rhizobium sp. group C strain 43-b & Cicer arietinum $\mathrm{L}$. & 5 \\
\hline R. loti NZP $2213^{\mathrm{T}}$ & Lotus tenuis & 9 \\
\hline \multicolumn{3}{|l|}{ R. galegae } \\
\hline ATCC $43677^{\mathrm{T}}$ & Galega orientalis & 28 \\
\hline HAMBI 1141 & Galega officinalis & 28 \\
\hline R. leguminosarum bv. viciae JISP24 & Pisum sativum & $\operatorname{MSDJ}^{b}$ \\
\hline $\begin{array}{l}\text { R. leguminosarum bv. trifolii USDA } \\
\text { 3Dim37 }\end{array}$ & Trifolium spp. & MSDJ \\
\hline R. huakuii CCBAU $2609^{\mathrm{T}}$ & Astragalus sinicus & 7 \\
\hline R. meliloti RCR 2011 & Medicago sativa & 29 \\
\hline R. fredii USDA $205^{\mathrm{T}}$ & Glycine $\max$ & 37 \\
\hline R. tropici CFN 299 & Phaseolus vulgaris & 29 \\
\hline \multicolumn{3}{|l|}{ B. japonicum } \\
\hline USDA 110 & Glycine $\max$ & 46 \\
\hline USDA 135 & Glycine $\max$ & MSDJ \\
\hline Bradyrhizobium sp. strain LL113 & Lupinus luteus & MSDJ \\
\hline \multicolumn{3}{|l|}{ Azorhizobium caulinodans } \\
\hline FY12 & Sesbania rostrata & 34 \\
\hline SG05 & Sesbania rostrata & 34 \\
\hline
\end{tabular}

${ }^{a}$ Groups $\mathrm{A}$ through $\mathrm{C}$ were described by Nour et al. (33). Strains were obtained from the Departamento de Microbiologia, E.T.S. de Ingenieros Agronomos, Universidad Politecnica, Madrid, Spain. USDA, United States Department of Agriculture, Beltsville, Md.; ATCC, American Type Culture Collection, Rockville, Md.; HAMBI, Culture Collection of the Department of Microbiology, University of Helsinki, Helsinki, Finland; NZP, Culture Collection of the Department for Scientific and Industrial Research, Palmerston North, New Zealand; CFN, Centro de Investigacion sobre Fijacion de Nitrogeno, Universidad Nacional Autonoma de Mexico, Cuernavaca, Mexico; FY and SG, Office de Recherche Scientifique et Technique Outre Mer, Dakar, Senegal; CCBAU, Culture Collection of Beijing Agricultural University, Beijing, People's Republic of China.

${ }^{b}$ MSDJ, Laboratoire de Microbiologie des Sols, Institut National de la Recherche Agronomique, Dijon, France.

Most strains were grown and maintained on yeast extractmannitol medium (40); yeast extract-lactate medium (34) was used for the Azorhizobium strains. These media were used for all procedures and experiments except extraction of chickpea rhizobium DNA; for DNA extraction maltose was used as the carbohydrate instead of mannitol in order to limit extra slime formation.

DNA extraction. DNA was extracted by using the procedure of Brenner et al. (3), with slight modifications. To further purify chickpea rhizobium DNA, extra chloroform-isoamyl alcohol extraction steps were performed.

Determination of base composition. The average $\mathrm{G}+\mathrm{C}$ contents of chickpea rhizobium DNAs were determined by high-performance liquid chromatography, as described previously (17). 
DNA-DNA hybridization and thermal stability of duplexes. Total DNAs from $R$. loti NZP $2213^{\mathrm{T}}, R$. galegae ATCC $43677^{\mathrm{T}}$, R. huakuii CCBAU $2609^{\mathrm{T}}$, and chickpea rhizobium strains UPM-Ca142, 3HOa9, UPM-Ca ${ }^{\mathrm{T}}$, and IC-60, were labelled in vitro by nick translation using tritium-labelled nucleotides (Amersham International, Amersham, England). DNA-DNA hybridization experiments were performed at the optimal temperature for DNA reassociation $\left(70^{\circ} \mathrm{C}\right)$ by using the $\mathrm{S} 1$ nuclease-trichloroacetic acid procedure of Grimont et al. (20).

The thermal stability of reassociated DNA was estimated by determining the temperature $\left(T_{m}\right)$ at which $50 \%$ of the doublestranded DNA became denatured and lysed by $\mathrm{S} 1$ nuclease, as described previously (8), with slight modifications (12). The temperature of the hybridization mixture was increased in $5^{\circ} \mathrm{C}$ steps from 70 to $100^{\circ} \mathrm{C}$. The divergence between DNAs was determined by calculating $\Delta T_{m}$ (the difference between the $T_{m}$ values of the heterologous and homologous duplexes).

PCR amplification and restriction enzyme analysis. Strains IC- 6 and UPM-Ca $7^{\mathrm{T}}$, which were representatives of the groups A and B (33), respectively, were compared with all of the reference strains except the $R$, huakuii strain. The oligonucleotides used to amplify the 16S-IGS region of the rRNA gene were 5'-GGAGAGTTAGATCTTGGCTCAG-3' (FGPS6-63) and 5'-CCGGGTTTCCCCATTCGG-3' (FGPL132'-38), which were derived from $m$ sequences of Frankia sp. (32). DNA was amplified by using the protocol of Mullis and Faloona (30), with some modifications. PCRs were performed in a final volume of $50 \mu \mathrm{l}$ under a thin surface layer of paraffin oil to prevent evaporation. Each reaction mixture contained approximately $0.5 \mu \mathrm{g}$ of genomic DNA, buffer $(10 \mu \mathrm{M}$ Tris $\mathrm{HCl}[\mathrm{pH}$ 8.2 ], $1.5 \mathrm{mM} \mathrm{MgCl}_{2}, 50 \mathrm{mM} \mathrm{KCl}, 0.01 \%$ [wt/vol] gelatin), 20 $\mu \mathrm{M}$ dATP, $20 \mu \mathrm{M}$ dTTP, $20 \mu \mathrm{M}$ dGTP, $20 \mu \mathrm{M}$ dCTP, each primer at a concentration of $0.1 \mu \mathrm{M}$, and $2.5 \mathrm{U}$ of TaqI DNA polymerase (Gibco-BRL, Cergy-Pontoise, France). Amplification was performed with a dry-block thermal cycler (Biometra Trio-thermoblock) by using the following program: initial denaturation for $3 \mathrm{~min}$ at $95^{\circ} \mathrm{C} ; 35$ cycles consisting of denaturation for $1 \mathrm{~min}$ at $95^{\circ} \mathrm{C}$, annealing for $1 \mathrm{~min}$ at $55^{\circ} \mathrm{C}$, and extension for $2 \mathrm{~min}$ at $72^{\circ} \mathrm{C}$; and finally extension for $3 \mathrm{~min}$ at $72^{\circ} \mathrm{C}$. To analyze the amplification products, $5-\mu l$ aliquots were electrophoresed on horizontal $0.8 \%$ (wt/vol) agarose gels in TBE buffer $(89 \mathrm{mM}$ Tris borate, $89 \mathrm{mM}$ boric acid, $2 \mathrm{mM}$ EDTA; $\mathrm{pH} 8$ ) at $4 \mathrm{~V} / \mathrm{cm}$ for $1 \mathrm{~h}$. The gels were stained in an aqueous solution containing $0.4 \mathrm{mg}$ of ethidium bromide per liter and were photographed under UV light $(302 \mathrm{~nm})$ by using Ilford type HP5 film.

Restriction enzyme analyses of PCR products were performed in a total volume of $20 \mu \mathrm{l}$ by using 10 to $12 \mathrm{U}$ of the following seven restriction endonucleases: $A l u \mathrm{I}, C f_{o} \mathrm{I}, M s p \mathrm{I}$, NdeII, and Sau96.1 supplied by Boehringer Mannheim, Meylan, France, and HaeIII and RsaI supplied by Gibco-BRL. The reaction conditions used were those recommended by the manufacturers. The restricted fragments were separated by horizontal electrophoresis in TBE buffer by using a 3\% (wt/vol) Nusieve agarose gel (FMC, Rockland, Maine) containing $1 \mu \mathrm{g}$ of ethidium bromide per $\mathrm{ml}$. The molecular weight standards used were 123-bp and 1-kb ladders (Gibco-BRL). The gels were electrophoresed at $2.3 \mathrm{~V} / \mathrm{cm}$ for $3 \mathrm{~h}$.

The distances that the restricted fragments migrated from the wells were measured, and the profiles were compared. Bands smaller than 90 bp were not taken into consideration, since they were not visualized reproducibly. The genetic relationship between two amplified DNAs was evaluated by using similarity coefficients $(F) . F$ values were calculated by using the following formula: $F=2 n_{\mathrm{xy}} / n_{\mathrm{x}}+n_{\mathrm{y}}$, where $n_{\mathrm{xy}}$ is the number of bands shared by strains $x$ and $y$ with all restriction endo- nucleases used and $n_{\mathrm{x}}$ and $n_{\mathrm{y}}$ are the total numbers of bands obtained for strains $\mathbf{x}$ and $\mathbf{y}$, respectively. A genetic distance for each pair of strains was estimated by using the mathematical model defined by Nei and Li (31), and a dendrogram was constructed by using the unweighted pair group method with arithmetic average algorithm of Sneath and Sokal (39).

Nucleotide sequencing of 16S rRNA genes. The following four chickpea rhizobia strains that were representatives of the previously described phylogenetic groups (33) were tested: group A strains IC-72M and UPM-Ca36 and group B strains UPM-Ca $7^{\mathrm{T}}$ and IC-2018. DNA coding for the preliminary section of the $16 \mathrm{~S}$ rRNA was amplified by using the conditions described above and oligonucleotides 5'-AGAGTTAGATC TTGGCTCAG-3' (FG1-157) and 5'-CCAGTGTGGCCG GTCGCCCTCTC-3' (FGPS305'-78), which were derived from $m$ sequences of Frankia sp. (32). To check the efficiency of the amplification reactions, 5- $\mu$ l portions of the PCR products were analyzed by electrophoresis on a $0.8 \%$ (wt/vol) agarose gel. The amplified products were purified with a GeneClean kit (Bio 101, La Jolla, Calif.) as specified by the manufacturer and then concentrated in $10 \mu \mathrm{l}$ of sterilized ultrapure water. A 1- $\mu \mathrm{l}$ aliquot was electrophoresed on a $0.8 \%$ (wt/vol) agarose gel for a final check before sequencing.

Sequencing was performed by using the dideoxy chain termination method of Sanger et al. (36), with the slight modifications described by Winship (43). The sequences of both strands of each amplified DNA were determined. The sequences were aligned and compared by using the Clustal V program (21). The $16 \mathrm{~S}$ rRNA sequences of the following organisms belonging to the Rhizobiaceae and related bacteria found in the GenBank Data Library were used for comparison (accession numbers are in parentheses): $R$. loti NZP $2213^{\mathrm{T}}$ (X63825), R. galegae ATCC $43677^{\mathrm{T}}$ (X63823), Rhizobium sp. (Phaseolus) strain H152 (L19662), Rhizobium sp. (Phaseolus) strain FL27 (M55234), Rhizobium sp. (Leucaena) strain TAL 1145 (X63824), $R$ tropici CIAT899 ${ }^{\mathrm{T}}$ (M55233), $R$. tropici IIA strain CO-5 (X67234), $R$. etli Olivia 4 (M55235), Rhizobium sp. (Medicago) strain Or191 (M55236), $R$ leguminosarum bv. phaseoli ATCC 8002 (M55494), R. méliloti ATCC $9930^{\mathrm{T}}$ (M55241), R. meliloti CC169 (M55242), R. fredii USDA 205 (M74163), Rochalimaea quintana (M73228), Agrobacterium tumefaciens LMG 196 (X67223), Agrobacterium rhizogenes LMG 152 (X67244), Agrobacterium rubi LMG $156^{\mathrm{T}}$ (X67228), Agrobacterium vitis $\mathrm{LMG} 8750^{\mathrm{T}}$ (X67225), Bradyrhizobium japonicum USDA 110 (M55485), Azorhizobium caulinodans ORS 571 (M55491), Rhodopseudomonas palustris 216 (M55496) Rhodospirillum rubrum ATCC 11170 (M55497), and Rhodobacter sphaeroides ATCC 17023 (M55498). Also included in the analysis was the 16S rRNA sequence of $R$. huakuii CCBAU 2609 ${ }^{\mathrm{T}}$ (accession number D12788), which was obtained from the EMBL Data Library. The partial $16 \mathrm{~S}$ ribosomal DNA (rDNA) sequence of a chickpea rhizobium strain determined in this study was deposited in the GenBank Data Library under accession number U07934. Similarity coefficients and observed numbers of differences were calculated. A distance matrix (25) was determined from the sequences, and unrooted phylogenetic trees were constructed by using the unweighted pair group method with arithmetic averages (39) and the neighbor-joining method (35).

Carbon substrate assimilation tests. Carbon substrate assimilation tests were performed by using six chickpea rhizobium strains that were representatives of groups $\mathrm{A}$ and $\mathrm{B}$, as well as $R$. loti NZP $2213^{\mathrm{T}}$ and $R$. galegae ATCC $43677^{\mathrm{T}}(R$. loti and $R$. galegae are two of the species that are most closely related to the chickpea rhizobia according to $16 \mathrm{~S}$ rRNA sequence data and PCR-RFLP results). Auxanographic API galleries (BioMérieux S. A., API system, La Balme des 


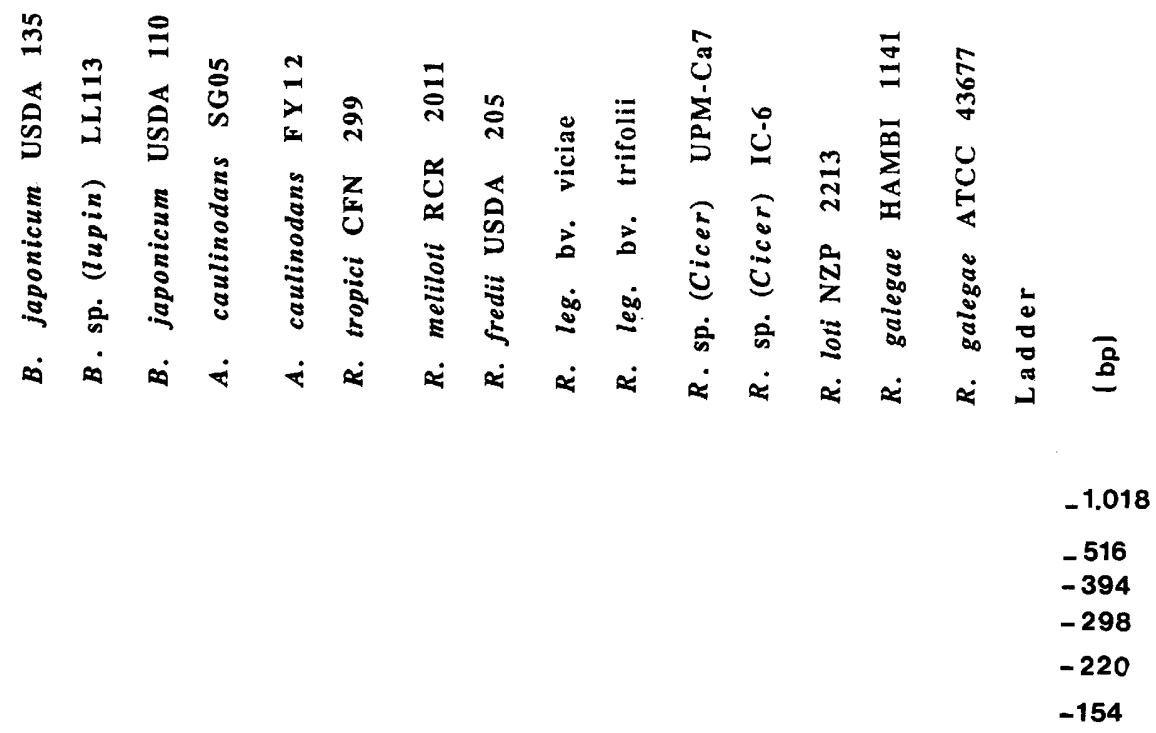

FIG. 1. RFLP analysis of amplified 16S-IGS rRNA genes from chickpea rhizobia and other members of the Rhizobiaceae, using restriction enzyme Sau96.1. B., Bradyrhizobium; A. Azorhizobium; R. Rhizobium; $R$. leg. bv. viceae, $R$. leguminosarum bv. viceae JISP24; $R$. leg. bv. trifolii, $R$. leguminosarum bv. trifolii USDA 3Dim37; B. sp. (lupin) LL113, Bradyrhizobium sp. (Lupinus) strain LL113.

Grottes, Vercieu, France) that included 49 carbohydrates (API $50 \mathrm{CH}$ ), 49 organic acids (LRA 50AO), and 49 amino acids (LRA 50AA) were used. The inoculation procedures were performed as recommended by the manufacturer, and the galleries were incubated at $28^{\circ} \mathrm{C}$. Growth (as shown by turbidity compared with a control) was recorded every $24 \mathrm{~h}$ for 5 consecutive days. The genetic distances between strains were estimated by using the Jaccard similarity coefficient (39). In this procedure the sum of effective matches was divided by the total possible number of matches for each pairwise calculation. Clustering based on a matrix of pairwise genetic distances was performed by using the unweighted pair group method with arithmetic average algorithm of Sneath and Sokal (39).

\section{RESULTS}

PCR-RFLP analysis of 16S-IGS rDNA. In a previous study two genetic groups, groups $\mathrm{A}$ and $\mathrm{B}$, were distinguished on the basis of the polymorphism of rRNA genes (33). In this study, two representative strains (one belonging to each group) were compared with reference strains belonging to known genera and species of the Rhizobiaceae. The DNAs of chickpea rhizobium strains UPM-Ca $7^{\mathbf{T}}$ and $\mathrm{IC}-6$ and reference strains were amplified with the 16S-IGS rRNA primers designated FGPS6-63 (5' end of the 16S subunit) and FGPL132'-38 (5' end of the $23 \mathrm{~S}$ subunit). An electrophoretic analysis of uncut PCR products revealed a single band having the same intensity for all strains. The sizes of the fragments represented by the bands were approximately $2,500 \mathrm{bp}$ for the chickpea rhizobium, $R$. galegae, $R$. loti, and azorhizobium strains; $2,800 \mathrm{bp}$ for the $R$. tropici, $R$. meliloti, $R$. leguminosarum bv. trifolii, $R$. leguminosarum bv. viciae, and $R$. fredii strains; $1,800 \mathrm{bp}$ for $B$. japonicum USDA $110 ; 2,000$ bp for Bradyrhizobium sp. (Lupinus); and 2,200 bp for B. japonicum USDA 135 .

The seven restriction enzymes which we used produced polymorphic patterns for the strains studied. $R s a$ I was the least discriminating enzyme since nine different profiles were found among the 15 strains tested. $C f o I, N d e I I$, and $M s p$ I produced a unique pattern for each strain. Restriction enzymes AluI, Sau96.1 (Fig. 1), and HaeIII produced 14 profiles; the profiles of $R$. loti NZP $2213^{\mathrm{T}}$ and UPM-Ca ${ }^{\mathrm{T}}$ were the same with these enzymes. The similarity coefficient values ranged from 0.236 to

istance (substitution/site)
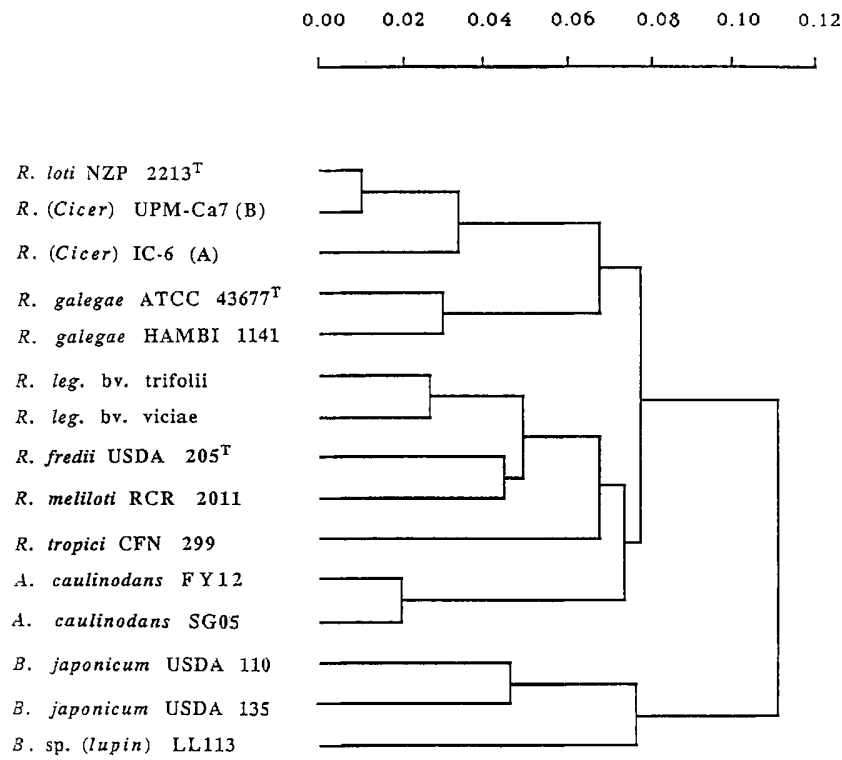

FIG. 2. Genetic distances, based on the results of an RFLP analysis of the amplified 16S-IGS rRNA region, between chickpea rhizobia and other members of the Rhizobiaceae. For abbreviations and the strains used, see the legend to Fig. 1. Groups A and B were described by Nour et al. (33). 
TABLE 2. Utilization of sole carbon sources by chickpea rhizobia, $R$. loti, and $R$. galegae

\begin{tabular}{|c|c|c|c|c|}
\hline Carbon sources & $\begin{array}{l}\text { Rhizobium sp. (Cicer) } \\
\text { group A }\end{array}$ & $\begin{array}{l}\text { Rhizobium sp. (Cicer) } \\
\text { group B }\end{array}$ & $\begin{array}{c}\text { R. loti } \\
\text { NZP 2213 }\end{array}$ & $\begin{array}{c}\text { R. galegae } \\
\text { ATCC } 43677^{\mathrm{T}}\end{array}$ \\
\hline $\begin{array}{l}\text { Glycerol, D-arabinose, L-arabinose, ribose, D-xylose, D-glucose, D- } \\
\text { fructose, D-mannose, rhamnose, inositol, mannitol, sorbitol, } N \text { - } \\
\text { acetylglucosamine, maltose, sucrose, trehalose, D-turanose, L-fucose, } \\
\text { D-arabitol, succinate, fumarate, D-malate, L-malate, pyruvate, L- } \\
\text { histidine, D-tryptophan, L-tryptophan, L-glutamate, DL-kynurenine, } \\
\text { L-proline, betaine, DL-4-aminobutyrate, 2-aminobenzoate, 3- } \\
\text { aminobenzoate, 4-aminobenzoate, glucosamine }\end{array}$ & + & + & + & + \\
\hline Galactose, DL-lactate, L-tyrosine & + & + & + & - \\
\hline D-Lyxose, DL-glycerate, L-aspartate & - & + & + & + \\
\hline L-Ornithine, $\beta$-alanine & - & + & + & - \\
\hline L-Xylose, L-alanine, L-leucine & - & + & - & - \\
\hline $\begin{array}{l}\text { Amygdalin, D-raffinose, gluconate, 5-ketogluconate, glutarate, DL-3- } \\
\text { OH-butyrate, D-tartrate, mesotartrate, } m \text {-OH-benzoate, tryptamine }\end{array}$ & - & - & - & + \\
\hline L-Phenylalanine, L-lysine & - & - & + & - \\
\hline
\end{tabular}

0.884 (data not shown). On the basis of the genetic distances obtained, we constructed a dendrogram (Fig. 2) which revealed the following two main groups: a Rhizobium-Azorhizobium group and a group consisting of Bradyrhizobium strains. These two groups were separated by a genetic distance of approximately 0.12 . $R$. loti, $R$. galegae, and the chickpea rhizobium strains formed a cluster which branched off from the remaining rhizobium and azorhizobium strains at a genetic distance of 0.08 . The chickpea rhizobia grouped with $R$. loti and were separated from the two $R$. galegae strains at a genetic distance of about 0.065 . Strain UPM-Ca $7^{\mathrm{T}}$, a group B strain, was separated from $R$. loti NZP $2213^{\mathrm{T}}$ at a genetic distance of 0.01 .

Phenotypic tests. The RFLP analysis of rRNA genes grouped the chickpea rhizobia close to $R$. loti and $R$. galegae. Thus, phenotypic tests were performed with the type strains of these two species and representative strains belonging to chickpea rhizobium groups $\mathrm{A}$ and $\mathrm{B}$. The results of tests to determine assimilation of sole carbon sources are shown in Table 2. The following 61 compounds were not assimilated by any of the strains: erythritol, $\beta$-methylxyloside, $\alpha$-methyl-Dmannoside, $\alpha$-methyl-D-glucoside, salicin, inulin, melezitose, amidon, glycogen, acetate, propionate, butyrate, isobutyrate, $N$-valerate, isovalerate, $N$-caproate, heptanoate, caprylate, pelargonate, caprate, oxalate, malonate, maleate, adipate, pimelate, suberate, azelate, L-tartrate, levulinate, citraconate, itaconate, mesaconate, aconitate, phenylacetate, benzoate, $o$-hydroxybenzoate, $p$-hydroxybenzoate, D-mandelate, L-mandelate, phthalate, isophthalate, terephthalate, glycine, D-alanine, L-isoleucine, L-norleucine, DL-norvaline, DL-2-aminobutyrate, L-serine, L-cysteine, L-methionine, L-citrulline, creatine, urea, acetamide, ethylamine, butylamine, amylamine, benzylamine, diaminobutane, and spermine. It is interesting that when we considered the amino acids utilized by at least one strain, $R$. galegae and the group A strains assimilated about $50 \%$ of these amino acids, whereas $R$. loti and the group B strains assimilated 77 and $70 \%$, respectively. In this respect, the chickpea rhizobium group A strains resemble $R$. galegae, whereas the group B strains resemble $R$. loti. When we took all 147 characteristics into account, the dendrogram obtained (Fig. 3) showed that $R$. loti NZP $2213^{\mathrm{T}}$ joins the group B chickpea rhizobium strains at a value of approximately 0.23 , and the group A chickpea rhizobium strains join at a distance of 0.32 . The type strain of $R$. galegae joins at a distance of 0.41 .

DNA sequencing. The fragment sequenced was located between nucleotide positions 44 and 337 in the Escherichia coli 16S rRNA sequence. This region, which has been used exten- sively for phylogenetic and taxonomic studies of members of the Rhizobiaceae $(11,27,44,46)$, is long and variable enough to permit reliable comparisons. The corresponding amplified DNA fragments obtained for strains IC-72M and UPM-Ca36 (group A) and for strains UPM-Ca7 ${ }^{\mathbf{T}}$ and IC-2018 (group B) were $260 \mathrm{bp}$ long. The four strains were identical at all 260 nucleotide positions determined (Fig. 4). When we compared these sequences with the $R$. lot $i$ and $R$. huakuii sequences, there were two and one nucleotide mismatches, respectively. The similarity coefficients for the chickpea rhizobia ranged from 0.772 with Rhodospirillum rubrum to 0.996 with $R$. huakuii (Table 3). When the sequence was compared with the $R$. lot $i$ and $R$. galegae sequences, the similarity coefficients were 0.992 and 0.972 , respectively. The phylogenetic tree obtained by using the partial 16S rRNA sequences is shown in Fig. 5. All of the chickpea rhizobium strains belonging to groups $A$ and $B$ belonged to the Rhizobium-Agrobacterium lineage, and none belonged to the Bradyrhizobium-Rhodopseudomonas lineage. The chickpea rhizobium strains formed a tight cluster with $R$. huakuii, $R$. loti, and $R$. galegae.

DNA analysis. The $\mathrm{G}+\mathrm{C}$ contents of the DNAs of representative chickpea rhizobium strains were as follows: strain 3HOa9, $64 \mathrm{~mol} \%$; and strains UPM-Ca $7^{\mathbf{T}}$ and IC-2091, 63 $\mathrm{mol} \%$.

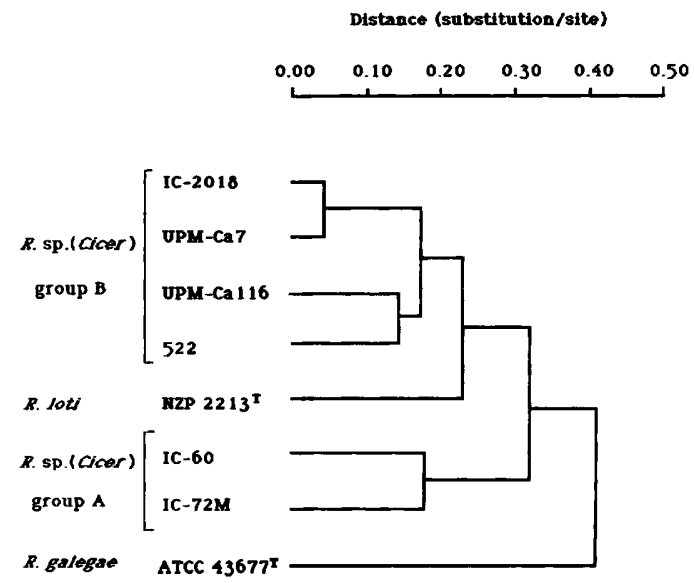

FIG. 3. Distances, based on sole carbon source assimilation data, between chickpea rhizobia, $R$. loti, and $R$. galegae. $R$., Rhizobium. Groups A and B have been described previously (33). 
1 R. SP. (C1cer) UPM-Ca7

2 R. lot1 NZP 2213

3 R. galegae ATCC 43677

$4 R$. huakuil CCBAU 2609

5 R. sp. (Phaseolus) H152

$6 R$. sp. (Leucaena) TAL 1145

7 R. tropicl CIAT 899

8 R. troplct C-05

9 R. sp. (Phaseolus) FL27

10 R. etli olivia 4

11 R. Sp. (Medicago) or191

12 R. leg. bv. phas. 8002

$13 \mathrm{R}$. melllot1 ATCC 9930

14 R. melllot 1 CC169

15 R. fredil USDA 205

16 A. tumefactens LMG 196

17 A. rh1zogenes LMG 152

18 A. rubl LMG 156

19 A. vitis LMG 8750

20 B. japonicum USDA 110

$21 \mathrm{Az}$. caul. ORS 571

22 Ro. quintana

23 Rp. palustris 216

$24 R b$. sphaeroldes ATCC 17023

25 Rs. rubrum ATCC 11170

1 R. sp. (C1cer) UPM-Ca7

2 R. lot1 NZP 2213

3 R. galegae ATCC 43677

$4 R$. huakuil CCBAU 2609

$5 R$ sp. (Phaseolus) H152

6 R. Sp. (Leucaena) TAL 1145

7 R. tropici CIAT 899

8 R. tropici C-05

9 R. sp. (Phaseolus) FL27

10 R. etli Olivia 4

11 R. sp. (Medicago) orl 191

12 R. leg. bv. phas. 8002

13 R. melllot 1 ATCC 9930

14 R. meliloti CCl69

15 R. fredif USDA 205

16 A. tumefaciens LMG 196

17 A. rhizogenes LMG 152

18 A. rubi LMG 156

19 A. vitis LMG 8750

20 B. Japonicum USDA 110

$21 \mathrm{Az}$. caulinodans ORS 571

22 Ro. quintana

23 Rp. palustr1s 216

$24 \mathrm{Rb}$. sphaero1des ATCC 17023

25 Rs. rubrum ATCC 11170

1 R. sp. (CICer) UPM-Ca 7

2 R. $\operatorname{lot} 1 \mathrm{NZP} 2213$

3 R. galegae ATCC 43677

$4 R$. huaku11 CCBAU 2609

5 R. sp. (Phaseolus) H152

6 R. sp. (Leucaena) TAL 114

$7 R$ trop1C1 CIAT 899

8 R. tropict C-05

9 R. sp. (Phaseolus) FL27

$10 \mathrm{R}$. etli Ollvia 4

11 R. sp. (Medicago) or191

12 R. leg. bv. phas. 8002

13 R. meliloti ATCC 9930

14 R. melilot 1 cc169

15 R. fredil USDA 205

16 A. tumefaciens LMG 196

17 A.rhizogenes IMG 152

18 A. rubi LMG 156

19 A. vitis LMG 8750

20 B. Japontcum USDA 110

$21 \mathrm{Az}$. caulinodans ORS 571

22 Ro. quintana

23 Rp. palustris 216

$24 \mathrm{Rb}$. sphaeroldes ATCC 17023

25 Rs. rubrum ATCC 11170
43

53

63

83

93

GGCTTAACA CATGCAAGTC GAGCG--CCC CGCAAGGGG- -AgCGgCAGA CGgGTGAGTa AGGCTTAACA CATGCAAGTC GAGCG--CCT CGCAAGAGG- -AGCGGCAGA CGGGTGAGTA AGGCTTAACA CATGCAAGTC GAGCG--CCT CGCAAGAGG- -AGCGGCAGA CGGGTGAGTA AGGCTTAACA CATGCAAGTC GAGCG--CCC CGCAAGGGG- -AGCGGCAGA CGGGTGAGTA AGGCTTAACA CATGCAAGTC GAGCG--CCC CGCAAGGGG- -AGCGGCAGA CGGGTGAGTA AGGCTTAACA CATGCAAGTC GAGCG--CCC CGCAAGGGG- -AGCGGCAGA CGGGTGAGTA AGGCTTAACA CATGCAAGTC GAGCG--CCC CGCAAGGGG- -AGCGGCAGA CGGGTGAGTA AGGCTTAACA CATGCAAGTC GAGCG--CCC CTCGAGGGG- -AGCGGCAGA CGGGTGAGTA AGGCTTAACA CATGCAAGTC GAGCG--CCC CGCAAGGGG- -AGCGGCAGA CGGGTGAGTA AGGCTTAACA CATGCAAGTC GAGCG--CCC CGCAAGgGG- -AGCGGCAGA CGGGTGAGTA AGGCTTAACA CATGCAAGTC GAGCG--CCC CGCAAGGGG- -AGCGGCAGA CGGGTGAGTA AGGCTTAACA CATGCAAGTC GAGCG--CCC CGCAAGgGG- -AGCGGCAGA CGGGTGAGTA AGGCTTAACA CATGCAAGTC GAGCG--CCC CGCAAGGGG- -AGCGGCAGA CGGGTGAGTA AGGCTTAACA CATGCAAGTC GAGCG--CCC CGCAAGGGG- -AGCGGCAGA CGGGTGAGTA AGGCTTAACA CATGCAAGTC GAGCG--CCC CGCAAGGGG- -AGCGGCAGA CGGGTGAGTA AGGCTTAACA CATGCAAGTC GAACG--CCC CGCAAGgGG- -AGTGGCAGA CGgGTGAGTA AGGCTTAACA CATGCAAGTC GAGCG--CCC CGCAAGGGG- -AGCGGCAGA CGGGTGAGTA AGGCTTAACA CATGCAAGTC GAACG--CTC CGCAAGGAG- -AGTGGCAGA CGGGTGAGTA AGGCTTAACA CATGCAAGTC GAGCG--CCT CGCAAGAGG- -AGCGGCAGA CGGGTGAGTA AGGCTTAACA CATGCAAGTC GAGCGGGCGT AGCAATACGT CAGCGGCAGA CGGGTGAGTA AGGCTTAACA CATGCAAGTC GAACGGGCCC -TTCG-GG-T CAGTGGCAGA CGGGTGAGTA AGGCTTAACA CATGCAAGTC GAGCGCACTC TTTTAGAGT- GAGCGGCAAA CGGGTGAGTA AGGCTTAACA CATGCAAGTC GAACGGGCGT AGCAATACGT CAGTGGCAGA CGGGTGAGTA AGGCTTAACA CATGCAAGTC GAGCGC-CGT AGCAATACGg -AGCGGCAGA CGGGTGAGTA AGGCTTAACA CATGCAAGTC GAACGCATCC CTTCG-GGAT GAGTGGCGCA CGGGTGAGTA
103
113
123
143
153
163 ACGCGTGGGA ATCTACCCAT CTCTACGGAA CAACTCCGGG AAACTGGAGC TAATACCGTA ACGCGTGGGA ATCTACCCAT CCCTACGGAA CAACTCCGGG AAACTGGAGC TAATACCGTA ACGCGTGGGA ATCTACCCAT CTCTACGGAA CAACTCCGGG AAACTGGAGC TAATACCGTA ACGCGTGGGA ATCTACCCAT CTCTACGGAA TAACTCAGGG AAACTTGTGC TAATACCGTA ACGCGTGGGA ATCTACCCTT TTCTACGGAA TAACGCAGGG AAACTTGTGC TAATACCGTA ACGCGTGGGA ATCTACCTTT TGCTACGGAA TAACGCAGGG AAACTTGTGC TAATACCGTA ACGCGTGGGA ATCTACCCTT TTCTACGGAA TAACGCAGGG AAACTTGTGC TAATACCGTA ACGCGTGGGA ACGTACCCTT TACTACGGAA TAACGCAGGG AAACTTGTGC TAATACCGTA ACGCGTGGGA ACGTACCCTT TACTACGGAA TAACGCAGGG AAACTTGTGC TAATACCGTA ACGCGTGGGA ACGTACCCTT TACTACGgAA TAACGCATGG AAACGTGTGC TAATACCGTA ACGCGTGGGA ATCTACCCTT GACTACGGAA TAACGCAGGG AAACTTGTGC TAATACCGTA ACGCGTGGGA ATCTACCCTT TTCTACGGAA TAACGCAGGG AAACTTGTGC TAATACCGTA ACGCGTGGGA ATCTACCCTT TTCTACGGAA TAACGCAGgG AAACTTGTGC TAATACCGTA ACGCGTGGGA ATCTACCCTT TTCTACGGAA TAACGCAGGG AAACTTGTGC TAATACCGTA ACGCGTGGGA ATCTACCGTG CCCTGCGGAA TAGCTCCGGG AAACTGGAAT TAATACCGCA ACGCGTGGGA ATCTACCCTT TTCTACGGAA TAACGCAGGG AAACTTGTGC TAATACCGTA ACGCGTGGGA ATCTACCCAA CCCTGCGGAA TAGCTCTGGG AAACTGGAAT TAATACCGCA ACGCGTGGGA ATCTACCGTA CCCTACGGAA TAGCTCCGGG AAACTGGAAT TAATACCGTA ACGCGTGGGA ACGTACCTTT TGGTTCGGAA CAACACAGGG AAACTTGTGC TAATACCGGA ACGCGTGGGA ACGTGCCCTT CAGTTCGGAA TAACCCAGGG AAACTTGGGC TAATACCGGA ACGCGTGGGA ATCTACCCAT CTCTACGGAA TAACACAGAG AAATTGTGC TAATACCGTA ACGCGTGGGA ACGTACCTTT TGGTTCGGAA CAACACAGGG AAACTTGTGC TAATACCGGA ACGCGTGGGA ATGTGCCCAA AGgTACGgAA CAACCAAGgG AAACTTTGGC TAATACCGTA ACACGTGGGA ACGTACCTTG GAGTGCGGA TAATCTTTGG AAACGAGGAC TAATACCGCA
173 *
183
193
203
213
223

TACGTCC-TT CGGGAGAAG ATTTATCGGA GATGGATGAG CCCGCGTTGg ATTAGCTAGT TACGTCC-TT CGGGAGAAAG ATTTATCGGA GATGGATGAG CCCGCGTTGG ATTAGCTAGT TACGCCC-TT CGGGGGAAAG ATTTATCGGG GATGGATGAG CCCGCGTTGG ATTAGCTAGT TACGTCC-TT CGGGAGAAAG ATTTATCGGA GATGGATGAG CCCGCGTTGG ATTAGCTAGT TACGCCC-TT CGGGGGAAAG ATTTATCGGA GATGGATGAG CCCGCGTTGG ATTAGCTAGT TGTGTCC-TT CGGGAGAAAG ATTTATCGGG GAAGGATGAG CCCGCGTTGG ATTAGCTAGT TGTGTCC-TT CGGGAGAAAG ATTTATCGGC AAGAGATGAG CCCGCGTTGG ATTAGCTAGT TGTGTCC-TT CGGGAGAAAG ATTTATCGGG AAAGGATGAG CCCGCGTTGG ATTAGCTAGT TGTGCCC-TT CGGGGGAAAG ATTTATCGGT AAGGGATCGG CCCGCGTTGG ATTAGCTAGT TGTGCCC-TT TGGGGGAAAG ATTTATCGGT AAAGGATCGG CCCGCGTTGG ATTAGCTAGT TGTGCCC-TT TGGGGGAAAG ATTTATCGGT AAAGGATCGG CCCGCGTTGG ATTAGCTAGT TGTGTCC-TT CGGGAGAAAG ATTTATCGGT CAAGGATGAG CCCGCGTTGG ATTAGCTAGT TGAGCCC-TT CGGGGGAAAG ATTTATCGGG AAAGGATGAG CCCGCGTTGG ATTAGCTAGT TAAGCCC-TT CGGGGGAAAG ATTTATCGgG AAAGGATGAG CCCGCGTTGG ATTAGCTAGT TGAGCCC-TT CGGGGGAAAG ATTTATCGGG AAAGGATGAG CCCGCGTTGG ATTAGCTAGT TACGCCC-TA CGGGGGAAAG ATTTATCGgG GTATGATGAG CCCGCGTTGG ATTAGCTAGT TGTGTCC-TT CGgGagAaA ATTTATCGgG AAAgGATGAg CCCGCGTTGg ATTAGCTAGT TACGCCC-TA CGGGGGAAAG ATTTATCGGG GATGGATGAG CCCGCGTTGG ATTAGCTAGT TACGCCC-TT CGgGGGAAAG ATTTATCGGG GTATGATGAG CCCGCGTTGG ATTAGCTAGT TAAGCCC-TT ACGGGGAAAG ATTTATCGCC GAAAGATCGG CCCGCGTCTG ATTAGCTAGT TACGTCC-GA AAGGAGAAAG ATTGATCGCT GAAGGATCGG CCCGCGTCTG ATTAGCTAGT TACGTCCCTC TGGGAGAAAG ATTTATCGGA GGTGGATGAG CCCGCGTTGG ATTAGCTAGT TAAGCCC-TT ACGGGGAAAG ATTTATCGCC GAAAGATCGG CCCGCGTCTG ATTAGCTAGT TGTGCCC-GA GAGGGGAAA ATTTATTGCC TTTGGAGCAG CCCGCGTCTG ATTAGCTAGT TACGCCC-TT AGGGGGAAAG ATTTATCGCT CCAAGATCGG CCCGCGTCCG ATTAGCTAGT 


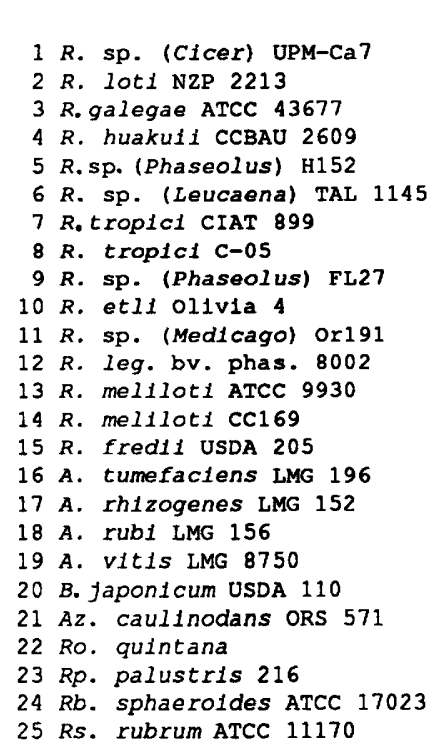

$2332 \quad 2 \begin{array}{lllll}* & 253 & 263 & 273 & 283\end{array}$

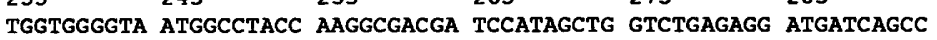
TGGTGGGGTA ATGGCCTACC AAGgCGACGA TCCATAGCTG GTCTGAGAgG ATGATCAGCC TGGTGGGGTA AAGGCCTACC AAGGCGACGA TCCATAGCTG GTCTGAGAGg ATGATCAGCC TGGTGGgGTA ATGGCCTACC AAgGCGACGA TCCATAGCTG GTCTGAGAGg ATGATCAGCC TGGTGGGGTA AAGGCCTACC AAGGCGACGA TCCATAGCTG GTCTGAGAGg ATGATCAGCC TGGTGGGGTA AAGGCCTACC AAgGCGACGA TCCATAGCTG GTCTGAGAGg ATGATCAGCC

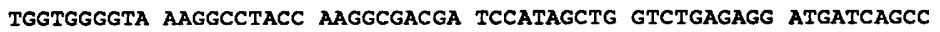
TGGTGGgGTA AAGGCCTACC AAgGCGACGA TCCATAGCTG GTCTGAgAgg ATGATCAgCC TGGTGGGGTA AAGGCCTACC AAGGCGACGA TCCATAGCTG GTCTGAGAGG ATGATCAGCC TGGTGGgGTA AAgGCCTACC AAgGCGACGA TCCATAgCTG GTCTGAGAgG ATGATCAgCC TGGTGGGGTA AAGGCCTACC AAgGCGACGA TCCATAGCTG GTCTGAGAGg ATGATCAGCC TGGTGGGGTA AAGGCCTACC AAGGCGACGA TCCATAGCTG GTCTGAGAGG ATGATCAGCC TGGTGGGGTA AAGGCCTACC AAGGCGACGA TCCATAGCTG GTCTGAGAGG ATGATCAGCC TGGTGGGGTA AAGGCCTACC AAGgCGACGA TCCATAGCTG GTCTGAGAGg ATGATCAGCC TGGTGGGGTA AAGGCCTACC AAGGCGACGA TCCATAGCTG GTCTGAGAGG ATGATCAGCC TGGTGGGGTA AAGGCCTACC AAGgCGACGA TCCATAGCTG GTCTGAGAGg ATGATCAGCC TGGTGGGGTA AAGGCCTACC AAGGCGACGA TCCATAGCTG GTCTGAGAGG ATGATCAGCC TGGTGGGGTA AAGGCCTACC AAGGCGACGA TCCATAGCTG GTCTGAGAGg ATGATCAGCC TGGTGGGGTA AAGGCCTACC AAGGCGACGA TCCATAGCTG GTCTGAGAGG ATGATCAGCC TGGTAGGGTA ACGGCCTACC AAGGCGACGA TCAGTAGCTG GTCTGAGAGG ATGATCAGCC TGGTGAGGTA ATGGCTCACC AAGgCGACGA TCAGTAGCTG GTCTGAGAgG ATGATCAGCC TGGTGAGGTA AGGGCTCACC AAGGCGACGA TCCATAGCTG GTCTGAGAGg ATGATCAGCC TGGTGAGGTA ATGGCTCACC AAGGCGACGA TCAGTAGCTG GTCTGAGAGG ATGATCAGCC 3 TGGTGGGGTA ACGGCCCACC AAGGCGACGA TCAGTAGCTG GTCTGAGAGG ATGATCAGCC 25 Rs. rubrum ATCC 11170 TGgCGgGgTA ATGGCCCACC AAGgCGACGA TCGgTAGCTg GTCTGAGAGG ATGGCAGCCA

\begin{tabular}{|c|c|c|}
\hline & $293 *$ & 303 \\
\hline 1 R. sp. (Clcer) UPM-Ca 7 & ACATTGGGAC & TGAGACACGG \\
\hline 2 R. $\operatorname{lot} i \mathrm{NZP} 2213$ & ACATTGGGAC & TGAGACACGG \\
\hline R.galegae ATCC 43677 & ACATTGGGAC & TGAGACACGG \\
\hline R. huakuii CCBAU 2609 & ACACTGGGAC & TGAGACACGG \\
\hline R. sp. (Phaseolus) H152 & ACATTGGGAC & TGAGACACGG \\
\hline R. sp. (Leucaena) TAL 1145 & ACATTGGGAC & TGAGACACGG \\
\hline R. tropici CIAT 899 & ACATTGGGAC & TGAGACACGG \\
\hline R. tropici C-05 & ACATTGGGAC & TGAGACACGG \\
\hline R. sp. (Phaseolus) FL27 & ACATTGGGAC & TGAGACACGG \\
\hline R. etil olivia 4 & ACATTGGGAC & TGAGACACGG \\
\hline R. sp. (Medicago) orl91 & ACATTGGGAC & TGAGACACGG \\
\hline R. leg. bv. phas. 8002 & ACATTGGGAC & TGAGACACGG \\
\hline R. melilot 1 ATCC 9930 & ACATTGGGAC & TGAGACACGG \\
\hline R. $\operatorname{mel110t} 1 \operatorname{cc} 169$ & ACATTGGGAC & TGAGACACGG \\
\hline R. fredil USDA 205 & ACATTGGGAC & TGAGACACGG \\
\hline A. tumefaciens LMG 196 & ACATTGGGAC & TGAGACACGG \\
\hline A. rhizogenes LMG 152 & ACATTGGGAC & TGAGACACGG \\
\hline A. rub1 LMG 156 & ACATTGGGAC & TGAGACACGG \\
\hline A.vitis LMG 8750 & ACATTGGGAC & TGAGACACGG \\
\hline B. Japonfcum USDA 110 & ACATTGGGAC & TGAGACACGG \\
\hline Az. caulinodans ORS 571 & ACATTGGGAC & TGAGACACGG \\
\hline Ro. quintana & ACACTGGGAC & TGAGACACGG \\
\hline Rp. palustris 216 & ACATTGGGAC & TGAGACACGG \\
\hline Rb. sphaeroides ATCC 1702 & ACATTGGGAC & TGAGACACGG \\
\hline Rs. rubrum ATCC 11170 & CACCTGGGAC & GAGACACGG \\
\hline
\end{tabular}

FIG. 4. Alignment of chickpea rhizobium partial 16S rRNA gene sequences with sequences of other members of the Rhizobiaceae and related bacteria. R., Rhizobium; R. leg. bv. phas., R. leguminosarum bv. phaseoli; A., Agrobacterium; B., Bradyrhizobium; Az., Azorhizobium; Ro., Rochalimaea; Rp., Rhodopseudomonas; Rb., Rhodobacter; Rs., Rhodospirillum. *, nucleotide mismatches between Rhizobium sp. (Cicer), A. loti, $R$. galegae, and $R$. huakuii.

On the basis of the results of the partial 16S rRNA sequence analysis, which placed the chickpea rhizobia close to $R$. loti, $R$. huakuii, and $R$. galegae, DNA relatedness values were therefore determined by using $R$. loti NZP $2213^{\mathrm{T}}, R$. galegae ATCC $43677^{\mathrm{T}}$, and $R$. huakuii CCBAU $2609^{\mathrm{T}}$ as the reference strains. The results are shown in Table 4 . $R$. loti gave low homology values (21 to $45 \%$ ) and $\Delta T_{m}$ values ranging from 5.5 to $11.5^{\circ} \mathrm{C}$ with all of the chickpea rhizobia. Likewise, $R$. galegae exhibited low levels of homology $(0.4$ to $8 \%)$ with both the chickpea rhizobia and $R$. loti. The homology values for $R$. huakuii and the chickpea rhizobia were 18 to $52 \%$. Moreover, the levels of DNA homology between three chickpea rhizobia (UPMCa142, IC-60, and 3HOa9) and other species, including $R$. leguminosarum bv. viciae, $R$. leguminosarum bv. trifolii, $R$. leguminosarum bv. phaseoli, $R$. meliloti, $R$. fredii, $B$. japonicum, and Bradyrhizobium sp. (Lupinus) were very low, ranging from 1 to $17 \%$ (data not shown). The levels of DNA homology between group A and B strains were tested by using two strains belonging to each group (group B strains UPM-Ca $7^{\mathrm{T}}$ and IC-2091 and group A strains IC-60 and H-45) (Table 5). Strain UPM-Ca $7^{\mathrm{T}}$ exhibited a high level of homology $(83 \%)$ with the other group B strain, IC-2091, and low levels of homology (36 to $38 \%$ ) with the group A strains. Similarly, IC-60 exhibited 77 and 26 to $29 \%$ homology with strain H-45 (group A) and the group B strains, respectively.

\section{DISCUSSION}

Previously, bacteria that are able to establish effective symbiotic relationships with chickpeas were classified as $R$. lot $i$ 


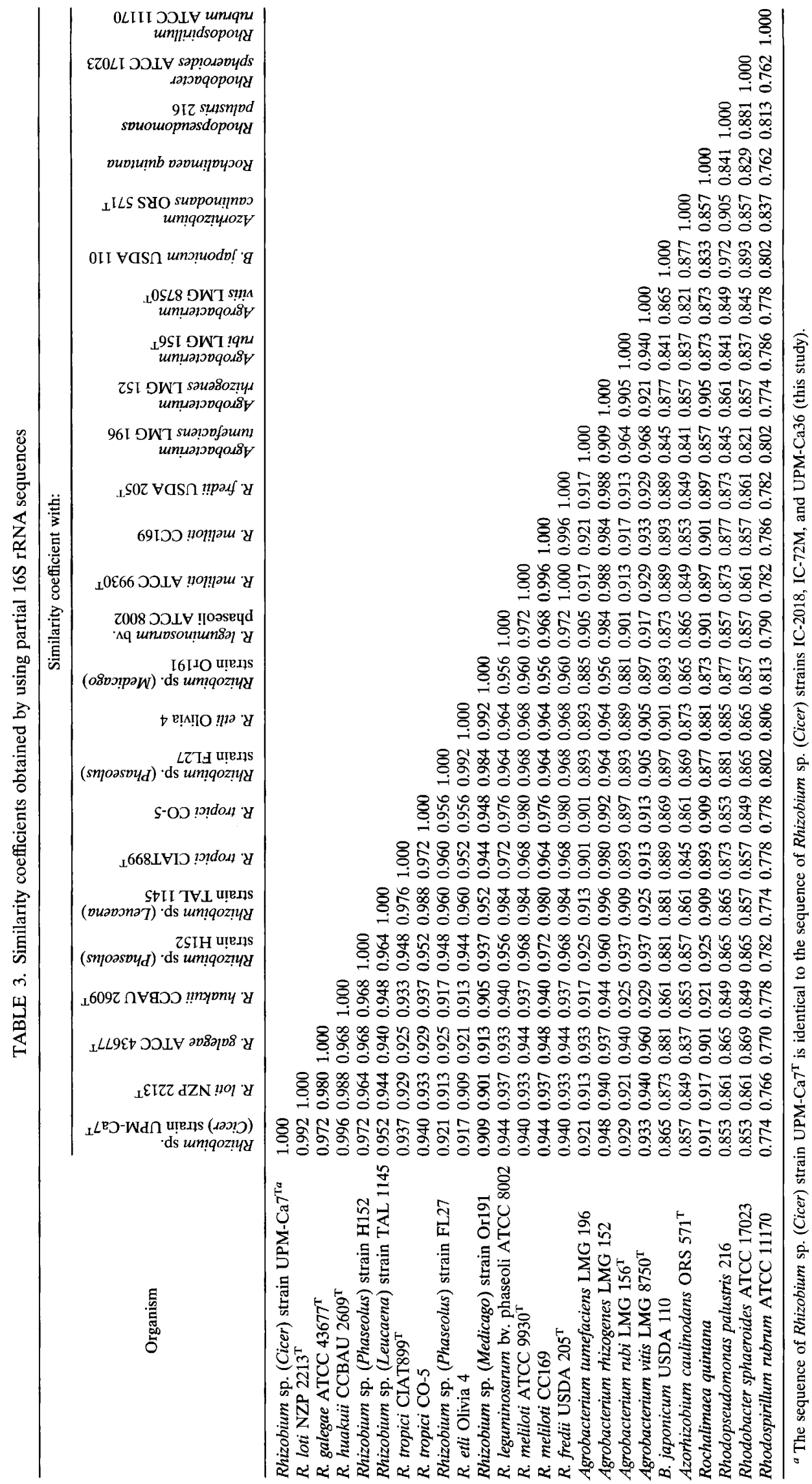




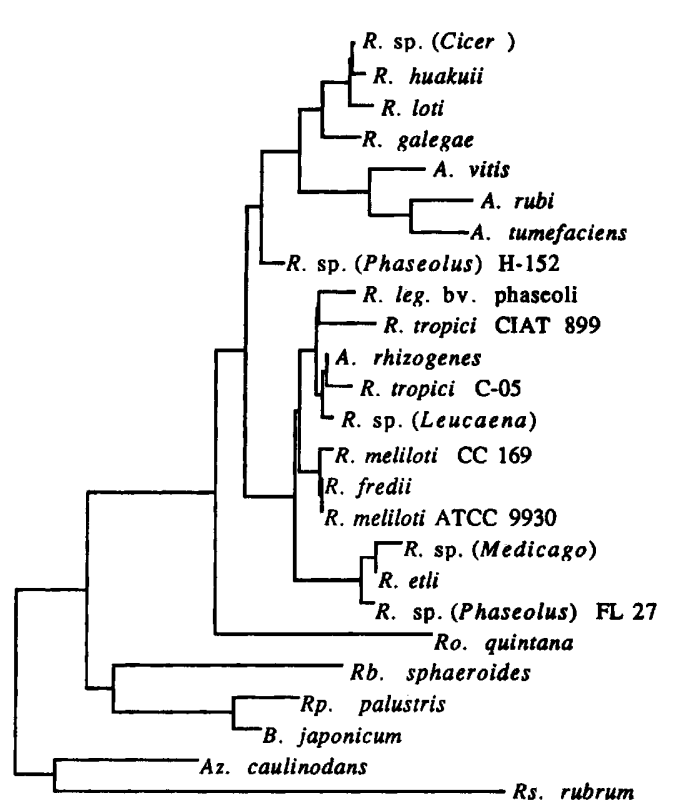

FIG. 5. Dendrogram derived from the aligned sequences of $16 \mathrm{~S}$ rDNA fragments obtained from members of the Rhizobiaceae and related bacteria. We obtained identical sequences for the following four Rhizobium sp. (Cicer) strains: group A strains IC-72M and UPM-Ca36 and group B strains UPM-Ca $7^{\mathrm{T}}$ and IC-2018. $R$., Rhizobium; $R$. leg. bv. phaseoli, $R$. leguminosarum bv. phaseoli; $A$., Agrobacterium; Ro., Rochalimaea; Rb., Rhodobacter; Rp., Rhodopseudomonas; Rs., Rhodospirillum; B., Bradyrhizobium; Az., Azorhizobium. The unmarked strains of species in the dendrogram are the following: $R$. huakuii CCBAU $2609^{\mathrm{T}}, R$. loti NZP $2213^{\mathrm{T}}, R$. galegae ATCC $43677^{\mathrm{T}}$, $A$. vitis LMG $8750^{\mathrm{T}}, A$. rubi LMG $156^{\mathrm{T}}, A$. tumefaciens LMG 196, $R$. leguminosarum bv. phaseoli ATCC 8002, $A$. rhizogenes LMG 152 , Rhizobium sp. (Leucaena) strain TAL 1145, $R$. fredii USDA $205^{\mathrm{T}}$, Rhizobium sp. (Medicago) strain Or191, $R$. etli Olivia 4, Rhodobacter sphaeroides ATCC 17023, Rhodopseudomonas palustris 216, B. japonicum USDA 110, Azorhizobium caulinodans ORS $571^{\mathrm{T}}$, and Rhodospirillum rubrum ATCC 11170.

(fast growers) or Bradyrhizobium sp. (slow growers) $(9,23)$. However, several authors have concluded that these organisms form a unique group on the basis of the specificity of the host plant-rhizobium relationship (16), serological and antigenic characteristics $(10,26)$, cultural traits, and the polymorphism of the nifHD genes (5). Recently, we reexamined the diversity among chickpea rhizobium strains, and our results, which were based on multilocus enzyme electrophoresis data, the polymorphism of the 16S-IGS rRNA genes, and phenotypic characteristics, led us to delineate two phylogenetic groups (33). Because of the relatively high levels of phenotypic and genotypic divergence that correlated with the variable generation times of these organisms, we questioned the taxonomic status of these two groups and particularly whether they belong to the same or different genera. Thus, in this study, in order to clarify the taxonomic position of these bacteria, we compared chickpea rhizobium strains with reference strains of genera and species belonging to the Rhizobiaceae by analyzing data from the following approaches: DNA-DNA hybridization, polymorphism of the 16S-IGS rRNA genes, partial 16S rRNA sequences, and phenotypic characteristics.

Amplification of the 16S-IGS rRNA gene generated identical 2,500-bp bands for all of the chickpea rhizobia. The deduced IGS fragment appeared to be relatively long (approx-
TABLE 4. Relative levels of homology between labelled $R$. loti, $R$. huakuii, or $R$. galegae DNA and unlabelled DNAs from Rhizobium sp. (Cicer arietinum L.) strains

\begin{tabular}{|c|c|c|c|}
\hline \multirow{2}{*}{ Strain } & \multicolumn{3}{|c|}{$\begin{array}{l}\% \text { Reassociation with } \\
{ }^{3} \mathrm{H} \text {-labelled DNA from: }\end{array}$} \\
\hline & $\begin{array}{c}\text { R. loti } \\
\text { NZP } 2213^{\mathrm{T}}\end{array}$ & $\begin{array}{c}\text { R. galegae } \\
\text { ATCC } 43677^{\mathrm{T}}\end{array}$ & $\begin{array}{c}\text { R. huakuii } \\
\text { CCBAU } 2609^{\mathrm{T}}\end{array}$ \\
\hline R. loti NZP $2213^{\mathrm{T}}$ & $100^{a}$ & 3 & $\mathrm{ND}^{b}$ \\
\hline R. galegae ATCC $43677^{\mathrm{T}}$ & 4 & 100 & ND \\
\hline R. huakuii CCBAU $2609^{\mathrm{T}}$ & ND & ND & 100 \\
\hline \multicolumn{4}{|l|}{ Rhizobium sp. (Cicer) } \\
\hline IC-60 & 21 & 8 & 29 \\
\hline H-45 & 30 & 5 & 28 \\
\hline IC-6 & $36(10)^{c}$ & 5 & 34 \\
\hline UPM-Ca142 & $25(10.5)$ & 5 & 35 \\
\hline UPM-Ca36 & 31 (11.5) & 7 & 29 \\
\hline Ca-7 & 23 & 7 & 27 \\
\hline IC-72M & 22 & 7 & 33 \\
\hline $\mathrm{UPM}-\mathrm{Ca} 7^{\mathrm{T}}$ & $44(7.5)$ & 3 & 19 \\
\hline 3HOa10 & 32 & 4 & 47 \\
\hline IC-2091 & $40(6.5)$ & 5 & 41 \\
\hline UPM-Ca116 & $45(5.5)$ & 4 & 49 \\
\hline $3 \mathrm{HOa} 9$ & $36(8.0)$ & 5 & 52 \\
\hline 522 & $41(7.0)$ & 6 & 42 \\
\hline IC-2018 & 34 & 1 & 35 \\
\hline USAB67 & $26(11.0)$ & 5 & 33 \\
\hline 43-b & 24 & 5 & 29 \\
\hline
\end{tabular}

${ }^{a}$ Level of relatedness at $70^{\circ} \mathrm{C}$

${ }^{b} \mathrm{ND}$, not determined.

${ }^{c}$ The numbers in parentheses are $\Delta T_{m}$ values (in degrees Celsius).

imately $1,000 \mathrm{bp}$ ), like the IGS fragments of other Rhizobium species (length, approximately 1,000 to $1,300 \mathrm{bp}$ ). In contrast, the IGSs of Bradyrhizobium strains were found to be 300 to 700 bp long, values which are comparable to those obtained for the IGSs of other bacteria $(200$ to $600 \mathrm{bp})(4,15,32)$. These results suggest that the chickpea rhizobium strains are more closely related to the genus Rhizobium than to the genus Bradyrhizobium.

The analyses of rRNA polymorphism and 16S rRNA sequences led to the same conclusions; i.e., the chickpea rhizobium strains were grouped with the Rhizobium species and far from the Bradyrhizobium cluster. The position of the chickpea rhizobium strains among the different Rhizobium species was the same whatever approach was used. All of the strains fell into a tight cluster which included $R$. loti and $R$. galegae. The $16 S$ rRNA sequence analysis showed that this cluster includes the $R$. huakuii strain. The genetic distances obtained by rRNA polymorphism analysis or phenotypic analysis placed the group $\mathrm{B}$ strains close to $R$. loti. Thus, even though the slowly growing chickpea rhizobium strains in group A were found to be less closely related to $R$. loti, they were shown to belong to the

TABLE 5. Levels of DNA relatedness between strains belonging to chickpea rhizobium groups $A$ and $B$

\begin{tabular}{|c|c|c|}
\hline \multirow[b]{2}{*}{ Strain } & \multicolumn{2}{|c|}{$\%$ Reassociation with ${ }^{3} \mathrm{H}$-labelled DNA from: } \\
\hline & $\begin{array}{c}\text { Group A strain } \\
\text { IC- } 60\end{array}$ & $\begin{array}{l}\text { Group B strain } \\
\text { UPM-Ca } 7^{\mathrm{T}}\end{array}$ \\
\hline IC-60 & $100^{a}$ & 36 \\
\hline $\mathrm{H}-45$ & 77 & 38 \\
\hline UPM-Ca $7^{\mathrm{T}}$ & 26 & 100 \\
\hline IC-2091 & 29 & 83 \\
\hline
\end{tabular}

${ }^{a}$ Level of relatedness at $70^{\circ} \mathrm{C}$. 
genus Rhizobium, demonstrating that the strain generation times which led to their classification as Bradyrhizobium strains are clearly a misleading criterion for classifying chickpea rhizobium isolates.

The four chickpea rhizobium strains that were used as representatives of groups $\mathrm{A}$ and $\mathrm{B}$ had identical partial $16 \mathrm{~S}$ rRNA sequences. Since the region which we sequenced is considered to be the most variable in 16S rDNA (13), these results suggest that groups $A$ and $B$ form a unique phylogenetic lineage. When the chickpea rhizobium sequence was compared with the $R$. huakuii and $R$. loti sequences, we found one and two different nucleotides, respectively (Fig. 4), resulting in similarity coefficients of 0.996 and 0.992 , respectively (Table 3 ). Because of these high similarity coefficients, separation of the chickpea rhizobia from $R$. loti and $R$. huakuii must be discussed. Similar values were found for the same 16S rRNA region with other members of the Rhizobiaceae. For example, a similarity coefficient of 0.996 was found for $R$. meliloti $\mathrm{CC} 169$ and $R$. fredii (Table 3 ). For these two species, sequencing of $97 \%$ of the $16 \mathrm{~S}$ rDNAs revealed eight or nine nucleotide mismatches. Other workers have also reported very high similarity coefficient values for different species. For instance, strains of Bacillus globisporus and Bacillus psychrophilus exhibited $99.8 \%$ sequence identity (14), and $R$. tropici IIA and IIB exhibited 99.6 and $99.4 \%$ similarity with Agrobacterium rhizogenes, respectively (42). It is now well accepted that although $16 \mathrm{~S}$ rRNA sequences can be used to establish relationships between genera and well-resolved species, very recently diverged species may not be recognizable perhaps because of molecular clock differences in the various taxa considered (14).

According to Wayne et al. (41) and Grimont (19), assignment of bacterial strains to species should be based on the results of total DNA relatedness studies. Strains that exhibit less than $70 \%$ reassociation and more than $5^{\circ} \mathrm{C}$ divergence do not belong to the same genomic species. The levels of DNA homology between the 16 chickpea rhizobia tested and $R$. loti, $R$. huakuii, and $R$. galegae were less than $52 \%$, clearly demonstrating that neither of our two groups can be assigned to any of these three species. In particular, $R$. loti, which has been proposed as the species to which the fast-growing chickpea rhizobium strains belong, exhibited low levels of DNA homology and $\Delta T_{m}$ values greater than $5^{\circ} \mathrm{C}$.

Phenotypic characteristics that distinguish between the chickpea rhizobium groups (groups $\mathrm{A}$ and $\mathrm{B}$ ) and $R$. loti are shown in Table 6. $R$. lot $i$ strains assimilate L-phenylalanine and L-lysine, whereas members of groups $\mathrm{A}$ and $\mathrm{B}$ do not. $R$. lot $i$ cannot grow at $40^{\circ} \mathrm{C}$ and does not tolerate $2 \%$ (wt/vol) $\mathrm{NaCl}$ (24), while the majority of chickpea rhizobia do grow at $40^{\circ} \mathrm{C}$ and tolerate $2 \%(\mathrm{wt} / \mathrm{vol}) \mathrm{NaCl}$. Most $R$. loti strains can grow at pH 4 (24); however, no growth is observed with chickpea rhizobia at this $\mathrm{pH}$. In contrast, $R$. loti cannot grow at $\mathrm{pH} 10$, while numerous chickpea rhizobia (all group B strains) can.

In summary, all of the chickpea rhizobium strains tested belong to the genus Rhizobium, regardless of their generation times. They are clearly separated from $R$. lot $i$ and other Rhizobium species on the basis of data from DNA relatedness, $16 \mathrm{~S}$ rRNA sequence, polymorphism of the 16S-IGS rRNA gene, and phenotypic characteristics. Within the chickpea rhizobia, the two previously described groups, groups A and B (33), belong to different lineages as determined by using various phenotypic and genotypic approaches, including low DNA-DNA homology values. On the basis of this evidence, we believe that the chickpea rhizobia belong in at least two different species. We propose that the group B chickpea rhizobia, which are more closely related to $R$. loti, should be assigned to a new species, Rhizobium ciceri. Presently, exten-
TABLE 6. Differentiating characteristics of $R$. ciceri, Rhizobium sp. (Cicer arietinum $\mathrm{L}$.) group $\mathrm{A}$, and $R$. loti

\begin{tabular}{|c|c|c|c|}
\hline Characteristic & R. ciceri & $\begin{array}{c}\text { Rhizobium sp. } \\
\text { (Cicer) } \\
\text { group A }\end{array}$ & $\begin{array}{c}\text { R. loti } \\
\text { NZP } 2213^{\mathrm{T}}\end{array}$ \\
\hline \multicolumn{4}{|l|}{$\begin{array}{l}\text { Utilization of the following } \\
\text { sole carbon sources: }\end{array}$} \\
\hline L-Phenylalanine, L-lysine & - & - & + \\
\hline $\begin{array}{l}\text { D-Lyxose, DL-glycerate, L- } \\
\text { aspartate }\end{array}$ & + & - & + \\
\hline L-Ornithine, $\beta$-alanine & + & - & - \\
\hline $\begin{array}{l}\text { L-xylose, L-alanine, L- } \\
\text { leucine }\end{array}$ & + & - & - \\
\hline Growth at $39-40^{\circ} \mathrm{C}$ & $+^{a}$ & + & - \\
\hline $\begin{array}{l}\text { Growth in the presence of } \\
2 \% \mathrm{NaCl}\end{array}$ & $+^{a}$ & + & - \\
\hline Growth at $\mathrm{pH} 4$ & - & - & $+^{b}$ \\
\hline Growth at pH 5 & + & - & + \\
\hline Growth at $\mathrm{pH} 10$ & + & $-c$ & - \\
\hline $\begin{array}{l}\text { Resistance to chlorampheni- } \\
\text { col }\end{array}$ & + & - & $\mathrm{ND}^{d}$ \\
\hline $\mathrm{G}+\mathrm{C}$ content $(\mathrm{mol} \%)$ & $63-64$ & $63-64$ & $59-64$ \\
\hline
\end{tabular}

${ }^{a}$ A total of $75 \%$ of the strains tested are positive.

${ }^{b}$ Between 11 and $89 \%$ of the strains tested are positive (24).

${ }^{c}$ Five of the seven strains tested are negative.

${ }^{d} \mathrm{ND}$, not determined.

sive DNA relatedness studies consisting of a large number of strains reveal a great heterogeneity among the group A strains; thus, more results will be necessary before naming new species for the members of this group.

Description of Rhizobium ciceri sp. nov. Rhizobium ciceri (ci' ce. ri. N. L. gen. n. ciceri, of Cicer). Gram-negative, aerobic, non-spore-forming rods. Colonies on yeast extract-mannitol agar are circular, opaque, and 2 to $4 \mathrm{~mm}$ in diameter within 3 to 5 days at $28^{\circ} \mathrm{C}$. The maximum temperature for growth is $40^{\circ} \mathrm{C}$ for most strains. These bacteria are able to grow on minimal media, can generally tolerate $2 \%$ (wt/vol) $\mathrm{NaCl}$, and grow at $\mathrm{pH}$ values of 5.0 to 10.0 . They are nalidixic acid, carbenicillin, chloramphenicol, and trimethoprim-sulfametoxazole resistant and are able to assimilate up to 73 compounds as sole carbon sources (33). The DNA G+C content ranges from 63 to $64 \mathrm{~mol} \%$. These bacteria are distinguished from other Rhizobium and Bradyrhizobium spp. and particularly from their closest relative, $R$. loti, on the basis of phenotypic and genomic characteristics.

Furthermore, $R$. ciceri can be differentiated from group A chickpea rhizobium strains on the basis of the results of multilocus enzyme electrophoresis and polymorphisms of amplified 16S-IGS rRNA genes (33). Group A strains cannot grow at $\mathrm{pH} 5$, generally cannot grow at $\mathrm{pH} 10$, and are highly susceptible to chloramphenicol. $R$. ciceri assimilates $70 \%$ of the amino acids which we tested, whereas the group A strains utilize $50 \%$. The following carbon sources are assimilated by $R$. ciceri and not by group A strains: D-lyxose, DL-glycerate, L-aspartate, L-ornithine, $\beta$-alanine, L-xylose, L-alanine, and L-leucine.

Strain UPM-Ca7, which was isolated from nodulated chickpeas grown in Spain, is the type strain. It has the characteristics described above for $R$. ciceri sp. nov. with respect to morphology, physiology, $\mathrm{G}+\mathrm{C}$ content, and genotype.

\section{ACKNOWLEDGMENTS}

We thank Chrystelle Chapelon for DNA sequencing, Stéphanie Orso for helpful discussions, Hélène Meugnier for technical assistance 
in $\mathrm{G}+\mathrm{C}$ content measurements, and T. Ruiz-Argueso and G. Laguerre for providing strains.

$S$. Nour received a joint research grant from the Institut National de la Recherche Agronomique, France, and the International Center for Agricultural Research in the Dry Areas, Aleppo, Syria.

\section{REFERENCES}

1. Arsac, J. F., and J. C. Cleyet-Marel. 1986. Serological and ecological studies of Rhizobium sp. (Cicer arietinum L.) by immunofluorescence and ELISA technique: competitive ability for nodule formation between Rhizobium strains. Plant Soil 94:411423.

2. Batzli, J. M., W. R. Graves, and P. V. Berkum. 1992. Diversity among rhizobia effective with Robinia pseudoacacia L. Appl. Environ. Microbiol. 58:2137-2143.

3. Brenner, D. J., A. C. McWorter, J. K. L. Knuston, and A. G. Steigerwalt. 1982. Escherichia vulneris: a new species of Enterobacteriaceae associated with human wounds. J. Clin. Microbiol. 15: 1133-1140.

4. Brosius, J., T. J. Dull, D. D. Sleeter, and H. F. Noller. 1981. Gene organization and primary structure of a ribosomal RNA operon from Escherichia coli. J. Mol. Biol. 148:107-127.

5. Cadahia, E., A. Leyvar, and T. Ruiz-Argueso. 1986. Indigenous plasmids and cultural characteristics of rhizobia nodulating chickpeas (Cicer arietinum L.). Arch. Microbiol. 146:239-244.

6. Chakrabarti, S. K., A. K. Mishra, and P. K. Chakrabartty. 1986. DNA homology studies of rhizobia from Cicer arietinum L. Can. J. Microbiol. 32:524-527

7. Chen, W. X., G. S. Li, Y. L. Qi, E. T. Wang, H. L. Yuan, and J. L. Li. 1991. Rhizobium huakuii sp. nov. isolated from the root nodules of Astragalus sinicus. Int. J. Syst. Bacteriol. 41:275-280.

8. Crosa, J. M., D. J. Brenner, and S. Falkow. 1973. Use of a single-strand-specific nuclease for analysis of bacterial and plasmid deoxyribonucleic acid homo- and heteroduplexes. J. Bacteriol. 115:904-911.

9. Crow, V. L., B. D. W. Jarvis, and R. M. Greenwood. 1981. Deoxyribonucleic acid homologies among acid-producing strains of Rhizobium. Int. J. Syst. Bacteriol. 31:152-172.

10. Dadarwal, K. R. 1980. Host bacterium factors involved in legume symbiosis. Indian J. Microbiol. 20:245-252.

11. Eardly, B. D., J. P. W. Young, and R. K. Selander. 1992. Phylogenetic position of Rhizobium sp. strain OR191, a symbiont of both Medicago sativa and Phaseolus vulgaris, based on partial sequences of the $16 \mathrm{~S}$ rRNA and nifH genes. Appl. Environ. Microbiol. 58:1809-1815.

12. Fernandez, M. P., H. Meugnier, P. A. D. Grimont, and R. Bardin. 1989. Deoxyribonucleic acid relatedness among members of the genus Frankia. Int. J. Syst. Bacteriol. 39:424-429.

13. Fernandez, M. P., S. Nazaret, P. Simonet, B. Cournoyer, and $P$. Normand. 1991. Structure of the genus Frankia, p. 629-633. In M. Polsinelli, R. Materassi, and M. Vincenzini (ed.), Nitrogen fixation. Kluwer Academic Publisher, Dordrecht, The Netherlands.

14. Fox, G. E., J. D. Wisotzkey, and P. Jurtshuk, Jr. 1992. How close is close: 16S rRNA sequence identity may not be sufficient to guarantee species identity. Int. J. Syst. Bacteriol. 42:166-170.

15. Garnier, T., B. Canard, and S. T. Cole. 1991. Cloning, mapping, and molecular characterization of the rRNA operons of Clostridium perfringens. J. Bacteriol. 173:5431-5438.

16. Gaur, Y. D., and A. N. Sen. 1979. Cross inoculation group specificity in Cicer rhizobium symbiosis. New Phytol. 83:745-754.

17. Gehrke, C. W., R. A. McCune, M. A. Gama Sao, M. Ehrlich, and K. C. Kuo. 1984. Quantitative reverse-phase high performance liquid chromatography of major and modified nucleosides in DNA. J. Chromatogr. 301:199-219.

18. Graham, P. H., M. J. Sadowsky, H. H. Keyser, Y. M. Barnet, R. S. Bradley, J. E. Cooper, D. J. De Ley, B. D. W. Jarvis, E. B. Roslycky, B. W. Strijdom, and J. P. W. Young. 1991. Proposed minimal standards for the description of new genera and species of rootand stem-nodulating bacteria. Int. J. Syst. Bacteriol. 41:582-587.

19. Grimont, P. A. D. 1988. Use of DNA reassociation in bacterial classification. Can. J. Bacteriol. 34:541-546.

20. Grimont, P. A. D., M. Y. Popoff, F. Grimont, C. Coynault, and M. Lemelin. 1980. Reproducibility and correlation study of three deoxyribonucleic acid hybridization procedures. Curr. Microbiol. 4:325-330.

21. Higgins, D. G., and P. M. Sharp. 1988. Clustal: a package for performing multiple alignment on a microcomputer. Gene 73:237244.

22. Jarvis, B. D. W., C. E. Pankhurst, and J. J. Patel. 1982. Rhizobium loti, a new species of legume-root nodule bacteria. Int. J. Syst. Bacteriol. 32:378-380.

23. Jordan, D. C. 1982. Transfer of Rhizobium japonicum Buchanan 1980 to Bradyrhizobium gen. nov., a genus of slow-growing root nodule bacteria from leguminous plants. Int. J. Syst. Bacteriol. 32:136-139.

24. Jordan, D. C. 1984. Family III. Rhizobiaceae, p. 234-242. In N. R Krieg and J. G. Holt (ed.), Bergey's manual of systematic bacteriology, vol. 1. The Williams \& Wilkins Co., Baltimore.

25. Jukes, T. H., and C. R. Cantor. 1969. Evolution of protein molecules, p. 21-132. In H. N. Munro (ed.), Mammalian protein metabolism. Academic Press, Inc., New York.

26. Kingsley, M. T., and B. B. Bohlool. 1983. Characterization of Rhizobium sp. (Cicer arietinum L.) by immunofluorescence, immunodiffusion and intrinsic antibiotic resistance. Can. J. Microbiol. 29:518-526.

27. Laguerre, G., M. P. Fernandez, V. Edel, P. Normand, and N. Amarger. 1993. Genomic heterogeneity among Rhizobium strains isolated from Phaseolus vulgaris L. assessed by DNA-DNA hybridization and analysis of $16 \mathrm{~S}$ ribosomal DNA sequences. Int. J. Syst. Bacteriol. 43:761-767.

28. Lindstrom, K. 1989. Rhizobium galegae, a new species of legume root nodule bacteria. Int. J. Syst. Bacteriol. 39:365-367.

29. Martinez-Romero, E., L. Segovia, F. M. Mercante, A. A. Franco, P. Graham, and M. A. Pardo. 1991. Rhizobium tropici, a novel species nodulating Phaseolus vulgaris $\mathrm{L}$. beans and Leucaena sp. trees. Int. J. Syst. Bacteriol. 41:417-426.

30. Mullis, K. B., and F. A. Faloona. 1987. Specific synthesis of DNA in vitro via a polymerase catalysed chain reaction. Methods Enzymol. 155:335-350.

31. Nei, M., and W. H. Li. 1979. Mathematical model for studying genetic variation in terms of restriction endonucleases. Proc. Natl. Acad. Sci. USA 76:5269-5273.

32. Normand, P., B. Cournoyer, P. Simonet, and S. Nazaret. 1992. Analysis of a ribosomal RNA operon in the actinomycete Frankia. Gene 111:119-124.

33. Nour, S., J. C. Cleyet-Marel, D. Beck, A. Effosse, and M. P. Fernandez. Genotypic and phenotypic diversity of Rhizobium isolated from chickpea (Cicer arietinum L.). Can. J. Microbiol., in press.

34. Rinaudo, G., S. Orenga, M. P. Fernandez, H. Meugnier, and R. Bardin. 1991. DNA homologies among members of the genus Azorhizobium and other stem- and root-nodulating bacteria isolated from the tropical legume Sesbania rostrata. Int. J. Syst. Bacteriol. 41:114-120.

35. Saitou, N., and M. Nei. 1987. A neighbour-joining method: a new method for reconstructing phylogenetic trees. Mol. Biol. Evol. 44:406-425.

36. Sanger, F., S. Nicklen, and A. R. Coulson. 1977. DNA sequencing with chain-terminating inhibitors. Proc. Natl. Acad. Sci. USA 74:5463-5467.

37. Scholla, M. H., J. A. Moorefield, and G. H. Elkan. 1984. Deoxyribonucleic acid homology between fast-growing soybean-nodulating bacteria and other rhizobia. Int. J. Syst. Bacteriol. 34:283-286.

38. Segovia, L., J. P. W. Young, and E. Martinez-Romero. 1993. Reclassification of American Rhizobium leguminosarum biovar phaseoli type I strains as Rhizobium etli sp. nov. Int. J. Syst. Bacteriol. 43:374-377.

39. Sneath, P. H. A., and R. R. Sokal. 1973. Numerical taxonomy. W. H. Freeman and Sons, San Francisco.

40. Vincent, J. M. 1970. A manual for the practical study of rootnodule bacteria. I. B. P. Handbook no. 15, p. 3-4. Blackwell Scientific Publications, Oxford

41. Wayne, L. G., D. J. Brenner, R. R. Colwell, P. A. D. Grimont, O. Kandler, M. I. Krichevsky, L. H. Moore, W. E. C. Moore, R. G. E. Murray, E. Stackebrandt, M. P. Starr, and H. G. Truper. 1987. Report of the Ad Hoc Committee on Reconciliation of Ap- 
proaches to Bacterial Systematics. Int. J. Syst. Bacteriol. 37:463464.

42. Willems, A., and M. D. Collins. 1993. Phylogenetic analysis of rhizobia and agrobacteria based on 16S rRNA gene sequences. Int. J. Syst. Bacteriol. 43:305-313.

43. Winship, P. R. 1989. An improved method for directly sequencing PCR amplified material using dimethyl sulfoxide. Nucleic Acids Res. 17:1266.

44. Woese, C. R. 1987. Bacterial evolution. Microbiol. Rev. 51:221271.
45. Young, J. P. 1985. Rhizobium population genetics: enzyme polymorphisms in isolates from peas, clover, beans and lucerne grown at the same site. J. Gen. Microbiol. 131:2399-2408.

46. Young, J. P. W., H. L. Downer, and B. D. Eardly. 1991. Phylogeny of the phototrophic Rhizobium strain BTAil by polymerase chain reaction-based sequencing of a $16 \mathrm{~S}$ rRNA gene segment. J. Bacteriol. 173:2271-2277.

47. Zhang, X., R. Harper, M. Karsisto, and K. Lindstrom. 1991. Diversity of Rhizobium bacteria isolated from the root nodules of leguminous trees. Int. J. Syst. Bacteriol. 41:104-113. 